\title{
Valuation Challenges Arising From the New Leasing Standard ASC 842: A Teaching Note
}

\author{
Bridget Lyons \\ Sacred Heart University
}

Accounting Standards Codification (ASC) Topic 842, the new accounting standard on leasing, aims to improve transparency related to leasing and to enable users of financial statements to more readily compare firms that lease with firms that borrow to buy assets. The standard is effective for 2020 and has had a significant impact on the balance sheets of many firms. This note provides an overview of the accounting changes and highlights key issues related to financial analysis and valuation with guidance on how to avoid common errors and accurately calculate and compare enterprise value, EBIT, EBITDA, valuation multiples and key valuation ratios. We also explain how financial data providers, Bloomberg, Capital IQ and FactSet, have adapted the information provided on these metrics.

Keywords: operating lease, valuation, ASC 842

\section{INTRODUCTION}

Sir David Tweedie, the former head of the International Accounting Standards Board (IASB), joked while speaking in Toronto in April 2008 that "One of my great ambitions before I die is to fly in an aircraft that is on an airline's balance sheet".

After decades of discussion, the Financial Accounting Standards Board in the US (FASB) and the IASB released new rules for reporting leases which became effective for public firms beginning in 2019. This is an area where the two accounting standards have not fully converged. Deloitte, PWC and KPMG have issued guides which detail the standards and the differences between US GAAP and IFRS (see reference section). While both accounting standards moved leased assets onto balance sheets, differences remain. Under IFRS, operating leases no longer exist. All leases are now financial leases. Under U.S. Generally Accepted Accounting Principles (GAAP), the new rules maintain a distinction between finance and operating leases and move operating leases onto the balance sheets as right of use assets with corresponding liabilities. The intent of the accounting change was to increase transparency related to operating leases and to enable users of financial statements to more readily compare firms that lease and firms that borrow to buy assets. While including all leases on the balance sheet does indeed provide valuable information and facilitates comparisons across firms, the new rules, and the differences across the two standards have created challenges for those calculating and interpreting valuation metrics and multiples such as enterprise value, EBIT and EV/EBITDA.

This note provides an overview of the accounting changes and highlights key issues related to valuation with guidance on how to avoid common errors and accurately calculate and compare enterprise value, 
EBIT, EBITDA, valuation multiples and key valuation ratios. We also explain how financial data providers, Bloomberg, Capital IQ and FactSet, have adapted the information provided on these metrics.

\section{OVERVIEW OF CHANGES TO THE ACCOUNTING FOR LEASES}

Public firms reporting under U.S. GAAP must now report for operating leases under the Accounting Standards Codification (ASC) Topic 842 which became effective for fiscal years ending after December 15, 2019. The new standard requires most lease obligations to be presented as a liability on the balance sheet, offset by a right-of-use asset related to the leased asset. The standard does not materially change the treatment of operating leases on the income statement or cash flow statement.

Under prior standards, leases were deemed to be either finance or operating based on several conditions, including the lease term as a percent of the useful life of the asset and the lease value compared to the asset value. The assets and liabilities of leases that were deemed finance leases were reported on a company's balance sheet, while the assets and liabilities of leases deemed operating leases did not appear on the balance sheet. Simply stated, short-term leases that did not involve a transfer of ownership were classified as operating leases and were "off balance sheet". If most of the value and useful life of the asset was included in the lease, then it was considered a financial lease and both the asset and associated liability appeared on the balance sheet. The liability was considered debt.

Despite the accounting treatment, for years many financial analysts, investors, rating agencies and creditors have employed a variety of techniques to adjust financial ratios and other information to treat operating leases as debt equivalents. The recommended treatment of leases is carefully explained in the 2009 paper by Aswath Damodaran and in the CFA Institute publication "Leases: What Investors Need to Know about the Standard" provides an excellent summary of similarities and difference between the standards.

Proponents of the change in accounting, including FASB, cite benefits including a clearer representation of a lessee's rights and obligations arising from leases and fewer opportunities for organizations to structure leasing transactions to achieve a particular outcome on the balance sheet.

\section{VALUATION CONSIDERATIONS}

This change in accounting provides additional transparency but also presents some challenges to those involved in valuation. For example, Ron Graziano, director of global accounting and tax at Credit Suisse, noted in a July 10, 2019 Wall Street Journal article that the new leasing standards may mislead investors. Brendan Houghton, partner of audit and assurance services at Deloitte \& Touche, commented in the February 2020 issue of Strategic Finance that the ratios used to value equities and assess a company's performance may look very different after the new standards are applied. In this section we detail five issues to consider, post ASC 842 when calculating firm value, valuation multiples and other valuation metrics and use JetBlue Airways as a case study.

We recommend that you consider:

1) the impact of finance and operating leases on each financial statement and identify relevant information in the $10 \mathrm{~K}$ or annual report

2) whether to include operating lease obligations when calculating enterprise value

3) how to consistently calculate EBIT and EBITDA across firms with different mixes of finance and operating leases or different accounting standards

4 ) if the numerator and denominator in valuation multiples are consistent with one another

5) how to incorporate operating leases into a valuation based on discounted cash flow analysis

\section{Understand the Impact on Each Financial Statement}

The classification of operating versus financial lease continues to impact where leases are shown on each of the financial statements. Understanding these differences is essential when calculating and interpreting valuation metrics. 
a) Firms utilizing operating leases must now recognize on the balance sheet a "right of use" asset that represents the lessee's right to use the asset for the lease term and a corresponding operating lease liability (though both standards allow an exception for very short term or low value leases). Assets obtained through financial leases continue to appear on the balance sheet as Property, Plant and Equipment and the related liability is called a finance lease though in the past these were referred to as either finance or capital leases. Figure 1 in Appendix 1 shows the JetBlue Balance Sheet from the $201910 \mathrm{~K}$ with information related to leases highlighted. Figure 2 shows details on leases provided in the notes to the financial statements. Under the new standard return on assets (ROA) and the ratio of liabilities/equity are more directly comparable across firms with different types of leases. For firms with operating leases the ROA will fall and the ratio of liabilities to equity will rise compared to historic levels as the lease assets and obligations move onto the balance sheet.

b) The income statement treatment of leases has not changed. As in the past, firms with operating leases report a constant single lease expense each period which is shown as an operating expense. It may be shown as a separate expense but is often included in Cost of Goods Sold or Selling, General \& Administrative expenses. The expense associated with finance leases is split between operating expenses (again included typically in either COGS or SG\&A) and interest expense. The result is that as in the past, reported operating profit is lower for firms using operating leases.

c) The cash flow statement treatment of leases has not changed. Operating lease expense is shown entirely in operating cash flows. Finance lease expense is split so that the interest portion appears in operating cash flows and the portion associated with debt repayment appears in financing cash flows. (See Figure 2 in Appendix 1.) This implies firms with operating leases will have lower operating cash flows and firms with finance leases will have lower financing cash flows.

d) The new standard requires extensive disclosure regarding the amount and timing of leases and lease related cash flows (See Appendix 1 Figure 2). This can prove helpful in calculating valuation metrics and in developing a DCF valuation.

TABLE 1

IMPACT OF OPERATING \& FINANCE LEASES ON FINANCIAL STATEMENTS

\begin{tabular}{|c|c|c|c|}
\hline \multirow[b]{2}{*}{ Lease type } & \multicolumn{2}{|c|}{ US GAAP } & \multirow{2}{*}{\begin{tabular}{|l|} 
IFRS \\
\end{tabular}} \\
\hline & Operating & Finance & \\
\hline \multicolumn{4}{|l|}{ Balance sheet } \\
\hline Asset & Right of use/Operating lease asset & PP\&E & Right of use asset or PP\&E \\
\hline Liability & Operating lease liability & Finance lease & Lease debt \\
\hline \multicolumn{4}{|l|}{ Income statement } \\
\hline In Operating expenses & $\begin{array}{l}\text { Operating lease expense } \\
\text { may be in COGS or SG\&A }\end{array}$ & Depreciation on asset & Depreciation on asset \\
\hline Interest expense & & Interest portion of lease payment & Interest portion of lease payment \\
\hline \multicolumn{4}{|l|}{ Cash flow statement } \\
\hline In Operating cash flows & Cash payment of operating lease & Interest expense related to lease & $\begin{array}{l}\text { Firms must follow the same } \\
\text { classification for interest paid }\end{array}$ \\
\hline In Financing cash flows & & $\begin{array}{l}\text { Principal repayment portion } \\
\text { of lease payment }\end{array}$ & $\begin{array}{l}\text { on other forms of financing and } \\
\text { may be shown in operating or } \\
\text { financing section }\end{array}$ \\
\hline
\end{tabular}

Let's consider an eample. A firm needs to acquire equipment and is considering 5 approaches:

1) Use all operating leases

2) Use all finance leases

3) Use bank debt 
4) Use half operating leases and half finance leases

5) Use short term operating leases

The purpose of this example is to illustrate key impacts so to make this visually clearer we assume that the annual expense for acquiring the asset is identical under all approaches and equals $\$ 6.5$. In reality the lease expenses would likely differ and the accounting will differ over time and across operating and financing leases even if the total lease payments are identical. For asset acquisition using finance leases or using debt, the payment of $\$ 6.5$ consists of $\$ 5.9$ in depreciation expense and $\$ 0.6$ in interest expense. For operating leases the entire lease expense appears as an oeprating expense. The example assumes Revenues of $\$ 100$ and operating expenses other than leases of $\$ 60$. The asset related to the lease is valued at $\$ 50$ in cases 1 through 4 . In case 5 the shorter length operating lease leads to a smaller value for the right of use asset and corresponding liability, here $\$ 17.7$. Other assets are assumed to be $\$ 150$ and other liabilities are assumed to be $\$ 75$. The resulting income statement and select financial ratios follow.

TABLE 2

LEASE IMPACT ON KEY METRICS

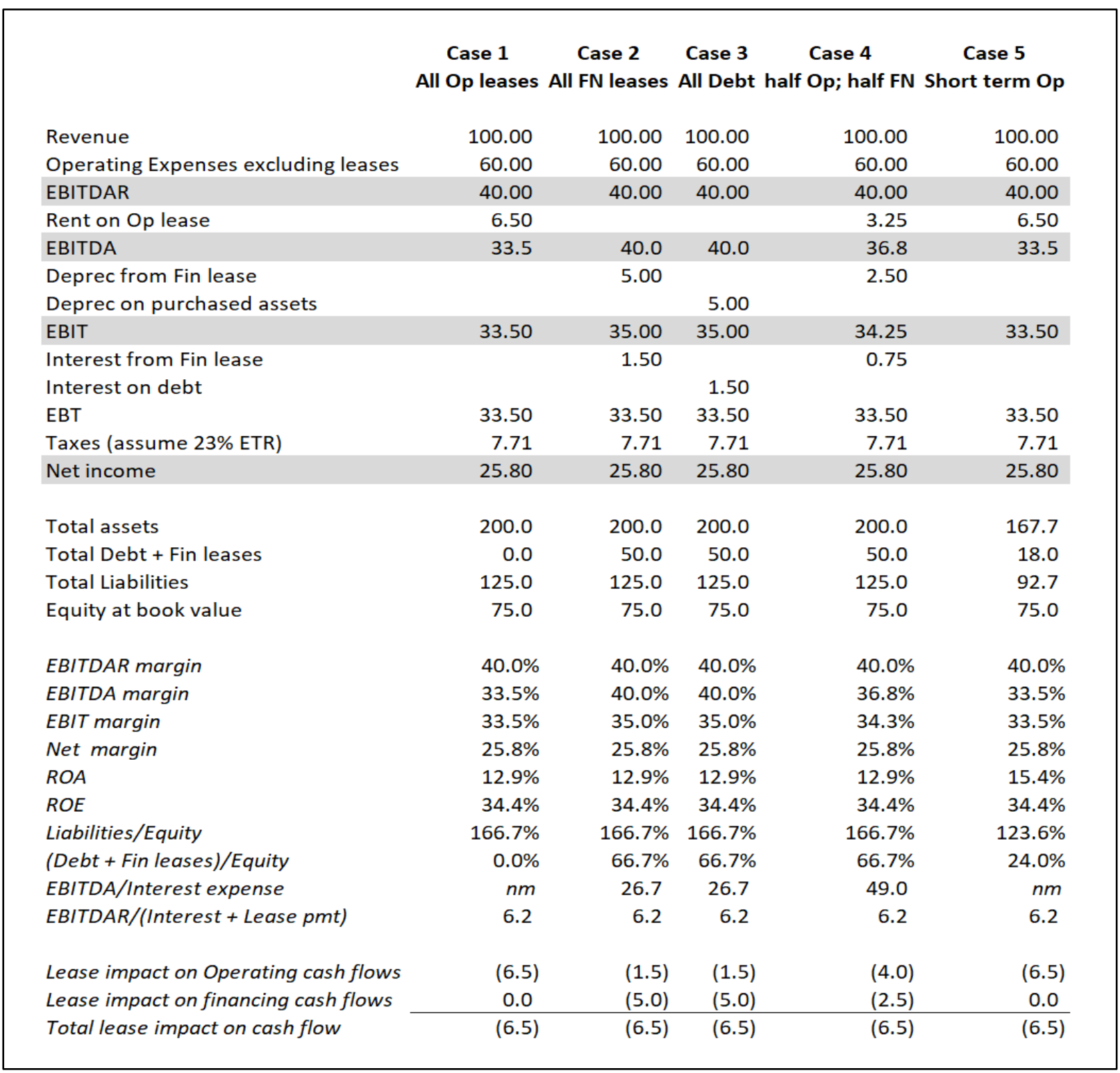


Key take-aways:

- EBITDAR is identical across approaches in this example due to our assumption of an identical lease expense. While the similarity is exaggerated here, EBITDAR does provide more comparabilty and therefore is often used to compare firms in industries where both operating and finance leases are heavily utilized.

- In the cases of all finance lease and all debt, EBITDA is greater than in the other cases since no lease expense is recorded.

- All metrics here are identical for Cases 2 and 3 since a finance lease is equivalent to debt.

- EBIT is lower when operating leases are used since the entire lease expense is considered an operating expense while the interest portion of a finance lease appears below EBIT.

- Net income is identical in this example due in part to our simplifying assumptions. In reality there could be slight differences across the approaches.

- Since all lease related assets are now on balance sheet the ROA is identical across Cases 1 through 4. In case 5 the shorter term lease leads to a lower value of the lease obligation and right of use asset so ROA is higher. At the same time using a short term operating lease leads to lower liabilities to equity.

- Operating leases lead to lower operating cash flows and higher financing cash flows.

\section{Should Enterprise Value Include Operating Leases?}

Enterprise value (EV), also called firm value, is an estimate of the current market value of a business and includes the value equity as well as the value of other sources of capital.

Enterprise value should reflect the value of all claimants and is typically defined as the sum of the market value of equity, net debt (financial debt less cash and equivalents), preferred stock and any noncontrolling interests. Post ASC 842, many are asking whether operating leases should be included in enterprise value.

While there is no consensus on whether to include operating leases in enterprise value, many analysts at investment banks include operating leases in EV particularly in industries where operating leases are signficant such as retail and transportation.

$\mathrm{EV}$ is commonly used to calculate valuation multiples such as EV/EBITDA and to derive equity value from enterprise value following valuation of a firm using discounted cash flow analysis.

Consider the EV formula first without and then with operating leases.

$$
E V=\text { Net debt }+ \text { Preferred Stock }+ \text { Market value of Equity }+ \text { Noncontrolling Interests }
$$

or

\section{$E V=$ Operating Leases + Net debt + Preferred Stock + Market value of Equity + Noncontrolling Interests}

The different formulations of enterprise value can be confusing but are neither new nor peculiar to operating leases. For years there have been different calculations of EV. Some include only the core operations of the business and exclude noncore assets and investments. Other calculations include all investments and non-core assets. Some distinguish core enterprise value from total enterprise value but these terms are not consistently used. Others debate including unfunded pension liabilities. It depends in part on why you are doing the analysis. The most important thing is to know what you are valuing, to communicate the results clearly and to be consistent. This will be very important as we turn to EV valuation multiples and valuation using the discounted cash flow technique (the next two sections).

An interesting wrinkle here is the term of the lease. As we saw in the earlier example, if a firm uses shorter term operating leases to acquire assets, it may report similar profitability but will have lower liabilities and therefore lower enterprise value than similar firms. 


\section{Calculate EBIT, EBITDA and EBITDAR Consistently}

Earnings before interest and taxes (EBIT) and Earnings before interest, taxes, depreciation and amortization (EBITDA) are so called non-GAAP measures because although they are widely used by financial analysts, investors and other finance professionals the measures are not defined by the accounting authorities. While there is some judgment, EBIT is generally viewed as operating profit restated to include only recurring operating revenues and expenses. One time expenses related to restruturing or litigation, for example, would be excluded in the EBIT and EBITDA calculations. EBIT and EBITDA are useful for comparing trends overtime at a given company or to benchmark companies to assess relative performance.

When comparing firms that utilizes operating leases with firms that use finance leases to obtain assets, EBIT and EBITDA no longer provide consistent comparisons as demonstrated in the example above. That is because the full operating lease expense appears in operating expenses subtracted to get to EBIT while only the depreciation portion of a finance lease is subtracted to get to EBIT. The other part of the finance lease expense is financial and appears in interest expense. EBITDA is also ineffective since here we deduct the entire operating lease expense but none of the expense related to the finance lease. Therefore in order to have a metric that allows us to compare firms using different mixes of operating and finance leases we need to add back to EBITDA the rent expense on operating leases so that we're comparing "apples to apples". Since there are no operating leases under IFRS reporting, when comparing US and international firms it's important to use a measure of EBITDA that adds back lease expense. It's a bit confusing because different names are used for this measure including EBITDAR, where the "R" stands for rent expense, and also just EBITDA which is the term Capital IQ, Bloomberg and FactSet now use.

\section{Ensure the Numerator and Denominator Are Consistent in EV Valuation Multiples}

One approach to valuation is to use relative valuation techniques, often referred to as comparables analysis or multiples. The basic concept is that similar assets should trade at similar prices. To apply this to firms, we analyze value by looking at the multiple of earnings a firm trades at - somewhat like price per square foot in real estate, price per carat with gems or price per ounce of cereal. Similar firms should trade at similar multiples of earnings while firms with stronger growth and margin prospects may trade at higher mutliples.

Valuation multiples commonly used in practice include:

- $\quad P / E=$ share price divided by earnings per share

- EV/EBIT = enterprise value divided by earnings before interest and taxes

- EV/EBITDA = enterprise value divided by earnings before interest, taxes, depreciation and amortization

- EVIEBITDAR = enterprise value divided by earnings before interest, taxes, depreciation, amortization and rent expense associated with leases

We have looked at several potential measures of enterprise value and several measures of recurring operating profit. It is essential to calculate the numerator and denominator consistently. The numerator is measure of value, the denominator is a value driver and reflects the earnings available to the providers of capital. Common equity holders have a claim on net income so we look at a P/E ratio since share price is driven by earnings per share. Since both equity owners and creditors have a claim on EBIT and EBITDA, the corresponding value driver must include earnings available to all providers of capital such as EBIT or EBITDA.

So how should operating leases be considered when calculating multiples? Either:

INCLUDE operating leases in enterprise value and use EBITDAR in the denominator

or,

\section{EXCLUDE operating leases in enterprise value and use EBITDA in the denominator}


The idea is if the claimants in EV exclude those with operating leases then the impact of the lease mut be captured by using earnings after deducting operating lease expense since these are the earnings they have a claim on. Thus we must match "apples to apples". When calculating multiples across firms with varying use of financial and operating leases, EV including operating leases divided by EBITDAR will typically provide a more comparable multiple.

Continuing with our example from above, we now include information related to enterprise value and calcuate valuation multiples. Assume the firm has 10 shares of equity trading at $\$ 9$ per share. Using this information and the extending our earlier example we find enterprise value and valuation mutliples for the 5 cases. Note that while the P/E and EV including operating leases/EBITDAR multiples are similar across the first 4 asset acquisition cases, the other multiples yield different results. Case 5 has a lower operating lease obligation so the EV and therefore the corresponding multiple is lower.

\section{LEASE IMPACT ON VALUATION MULTIPLES}

\begin{tabular}{|lrrrrr|}
\hline & \multicolumn{1}{c}{ Case 1 } & Case 2 & Case 3 & Case 4 & Case 5 \\
Assumptions & All Op leases & All FN leases & All Debt half Op; half FN Short term Op \\
\# shares & 10.0 & 10.0 & 10.0 & 10.0 & 10.0 \\
Share price & 9.0 & 9.0 & 9.0 & 9.0 & 9.0 \\
Market cap & 90.0 & 90.0 & 90.0 & 90.0 & 90.0 \\
Cash & 15.0 & 15.0 & 15.0 & 15.0 & 15.0 \\
Debt & 0.0 & 50.0 & 50.0 & 25.0 & 0.0 \\
Net debt & $(15.0)$ & 35.0 & 35.0 & 10.0 & $(15.0)$ \\
& & & & & \\
EPS & $\$ 2.58$ & $\$ 2.58$ & $\$ 2.58$ & $\$ 2.58$ & $\$ 2.58$ \\
P/E & 3.5 & 3.5 & 3.5 & 3.5 & 3.5 \\
& & & & & \\
EV excluding op leases & 75.0 & 125.0 & 125.0 & 100.0 & 75.0 \\
EV excluding op leases/EBIT & 2.2 & 3.6 & 3.6 & 2.9 & 2.2 \\
EV excluding op leases/EBITDA & 2.2 & 3.1 & 3.1 & 2.7 & 2.2 \\
EV excluding op leases/EBITDAR & 1.9 & 3.1 & 3.1 & 2.5 & 1.9 \\
& & & & & \\
Operating lease liability & 50.0 & 0.0 & 0.0 & 25.0 & 17.7 \\
EV including op leases & 125.0 & 125.0 & 125.0 & 125.0 & 92.7 \\
EV including op leases/EBIT & 3.7 & 3.6 & 3.6 & 3.6 & 2.8 \\
EV including op leases/EBITDA & 3.7 & 3.1 & 3.1 & 3.4 & 2.8 \\
EV including op leases/EBITDAR & 3.1 & 3.1 & 3.1 & 3.1 & 2.3 \\
\hline
\end{tabular}

\section{Consider How to Incorporate Operating Leases in Discounted Cash Flow Valuation}

Discounted cash flow analysis (DCF) is the other technique commonly used to value firms (in addition to multiples or comparables analysis). Conceptually the DCF technique values a firm as the present value of expected future free cash flows where the firm's weighted average cost of capital is used as the discount rate. Historically the impact of operating leases was captured by including the operating lease expense as an expense to get to free cash flow. Once the enterprise value is determined, the value of the equity can be found by subtracting the value accruing to other claimants. Conceptually, the operating lease reduces equity value. This can be captured either by reducing the forecasted cash flows by the operating lease expense or by considering the lease obligation to represent a claim like a finance lease. 


\title{
Alternative 1: Operating Lease Expenses Are Included in FCF
}

\author{
Free cash flow $=E B I T *(1-$ tax rate $)$ \\ Plus Depreciation on $P P \& E$ \\ Plus Amortization \\ Less New Capital expenditures \\ Less investment in operating working capital
}

Discount projected free cash flows at the weighted average cost of capital to find enterprise value. Then subtract other claims on enterprise value to find the implied equity value.

$$
\text { Equity = Enterprise value }- \text { Net debt }- \text { Preferred stock }- \text { Noncontrolling interests }
$$

Note that EBIT is stated after accounting for the full operating lease expense and the depreciation portion of the finance lease expense to take into account the tax impact of depreciation. Depreciation on assets is then added back since it was a non cash expense and any new capital expenditures are subtracted.

When determining equity value from enterprise value, there is no need to subtract the value of operating leases since free cash flow is stated after operating lease expense.

\section{Alternative 2: Adjust FCF to Treat Operating Leases as Finance Leases}

Or, the DCF technique could be adjusted to treat operating leases like finance leases in the calculation of free cash flow to the firm and then account for operating leases like finance leases in the EV to equity adjustments. In this approach only the depreciation portion of the operating lease is included as an expense when calculating EBIT. As with finance leases, the interest portion is excluded. Any new investment in right of use assets must be deducted in deriving free cash flow as with capital expenditures related to finance leases.

Free cash flow $=$ EBIT stated after depreciation of both finance and operating lease assets *(1tax rate)

Plus Depreciation on both finance and operating lease assets

Plus Amortization

Less New Capital expenditures

Less New investments in right of use assets

Less investment in operating working capital

Discount projected free cash flow at the weighted average cost of capital to find enterprise value. Then subtract other claims on enterprise value to find the implied equity value.

$$
\begin{gathered}
\text { Equity }=\text { Enterprise value }- \text { Net debt }- \text { Operating lease obligations }- \text { Preferred stock }- \text { Noncontrolling } \\
\text { interests }
\end{gathered}
$$

I do not recommend this second approach because it quickly becomes complex. First, the free cash flow calculation requires deducting the depreciation portion of both operating and finance leases. This is not an issue for finance leases but the operating lease expense breakout between depreciation and interest may not be provided in the notes and would therefore need to be estimated. JetBlue does provide this breakout - See Appendix 1 Figure 2. Second, free cash flow needs to be adjusted for the expected increase in right of use assets related to operating leases (analogous to capital expenditures) but there is very little information available to forecast this expenditure since the accounting is new. Third, if operating leases are treated as debt they must be included in the capital structure and in the calculation of the firm's weighted average cost of capital (WACC). 
The first approach is more straightforward and also has the benefit of using a known value - the lease expense. In the notes to the financial statements, firms provide detailed information on historic and future lease commitments. The second approach includes more uncertainty and more opportunities for error.

\section{WHAT ARE THE FINANCIAL DATA PROVIDERS REPORTING?}

Prior to the adoptions of ASC 842 and IFRS 16 most providers followed the accounting treatment of operating and finance leases but included additional information related to operating leases in some ratios and metrics. Following the new standards, Bloomberg, Capital IQ and FactSet have all made adjustments to how data is reported.

The treatment as of early 2021 follows. Generally speaking, Bloomberg, Capital IQ and FactSet are now treating operating leases as finance leases in an attempt to report consistently across firms despite the type of lease used or the accounting standard adopted. As Capital IQ puts it, "Capital IQ fundamentals aim to be accounting standard agnostic".

- The operating lease obligation is included with debt and the asset appears in PP\&E.

- EBIT calculations have not been adjusted.

- All provide a measure of EBITDA stated after adding back the lease expense for both operating and finance leases. It is called EBITDA at these providers though many others continue to use the term EBITDAR.

- Enterprise value includes operating lease obligations.

- Supplemental information breaking out the interest and depreciation components of operating leases is often provided.

- Each provider has developed new metrics to assist users and provide additional information.

At Bloomberg, EBITDAR is also reported and includes the impact of low value or short term operating leases. Under both US GAAP and IFRS very low value or very short term leases need not be capitalized. Bloomberg has added codes to assist users in identifying lease rleated information on each of the financial statements. EV includes operating leases but Bloomberg has added a metric "Enterprise value excluding operating leases".

Capital IQ has added 17 additional supplemental data items related to the change. The firm has also provided detailed information on how measures like EV and EBITDA have been adjusted to provide consistency across standards and for use in valuation multiples. As shown below, Cap IQ reports the "lease adustment for EBITDA".

At FactSet the default for enterprise value is to include operating leases. However, there is an option for clients to exclude the operating lease value from the total EV calculation. Like Bloomberg and Capital IQ, EBITDA adds back operating lease expense. Since many clients requested to have a way to exclude the leasing effects there are now separate codes for data selected that allow these items to be excluded.

\section{Example: Capital IQ Information on JetBlue Airways}

Below we show select information for Jet Blue as provided by Capital IQ. Information is shown as of mid-February 2020. This date was selected to capture the financials through 2019 to allow for inclusion of the lease related changes while avoiding most of the Covid impact which wreaked havoc on earnings and valuation multiples in 2020.

\section{Enterprise Value Calculation}

The picture below shows the inclusion of operating and finance leases (which Cap IQ calls capital leases) in the enterprise value calculation. Note that enterprise value of $\$ 7,834.9$ million includes total debt of $\$ 3,152$ million which is shown to include both operating and finance liabilities (here I showed the detail for long term leases). The value of $\$ 7,951$ million is the total capital based on book values and includes total debt rather than net debt. 
FIGURE 1

JETBLUE ENTERPRISE VALUE

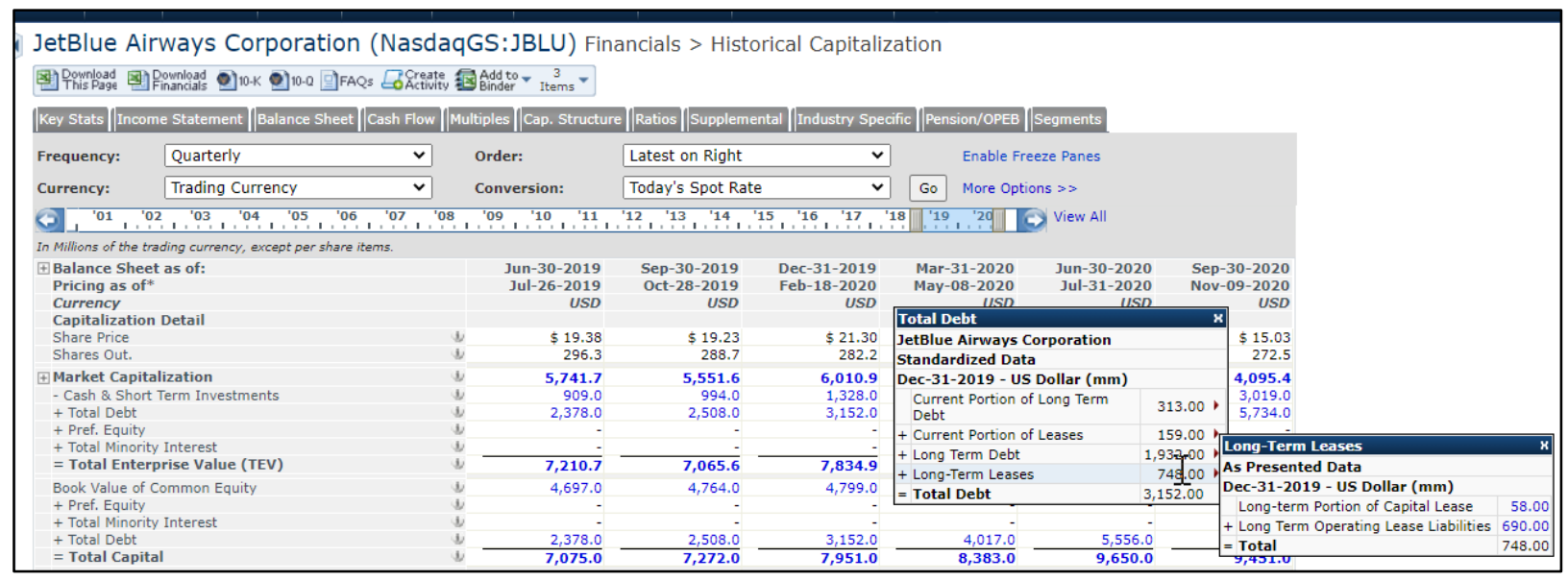

Air France reports under IFRS so has only finance leases. The total debt and breakout are shown below. Note that leases are simply referred to as lease debt.

FIGURE 2

AIR FRANCE ENTERPRISE

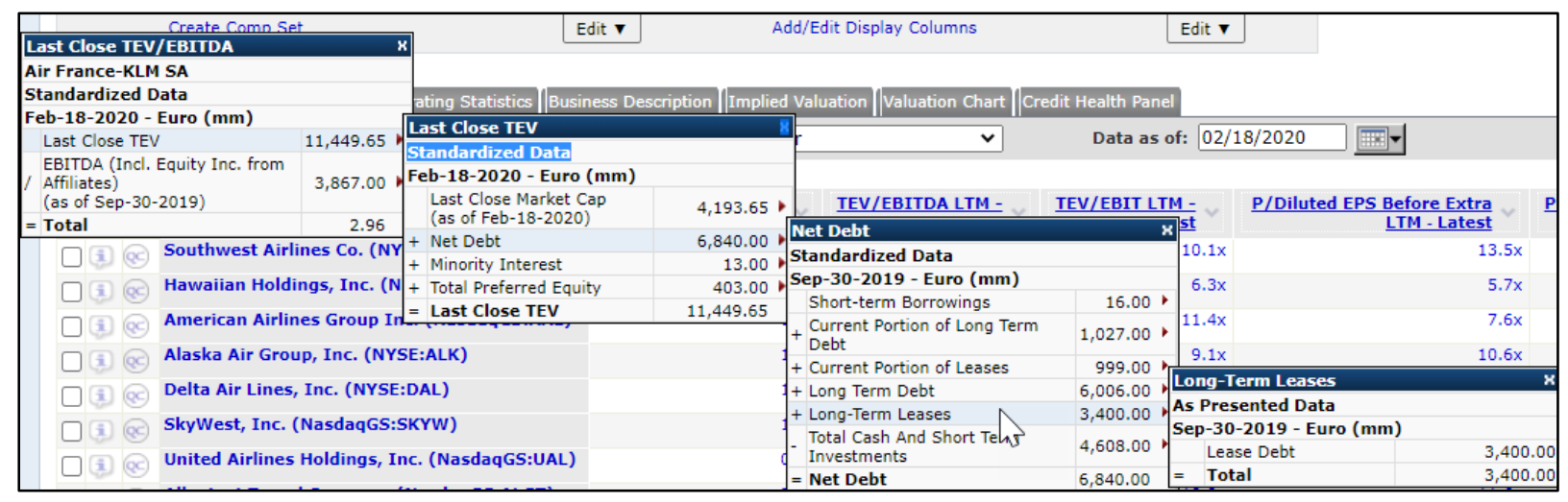

\section{Multiples Calculation}

Below is a screenshot displaying trading multiples for JetBlue and some peers. Next, a detailed look at the calculations for JetBlue and Air France is provided. JetBlue reports under US GAAP and Air France reports under IFRS. Capital IQ has attempted to facilitate comparisons across the standards. 
FIGURE 3

\section{JETBLUE MULTIPLES}

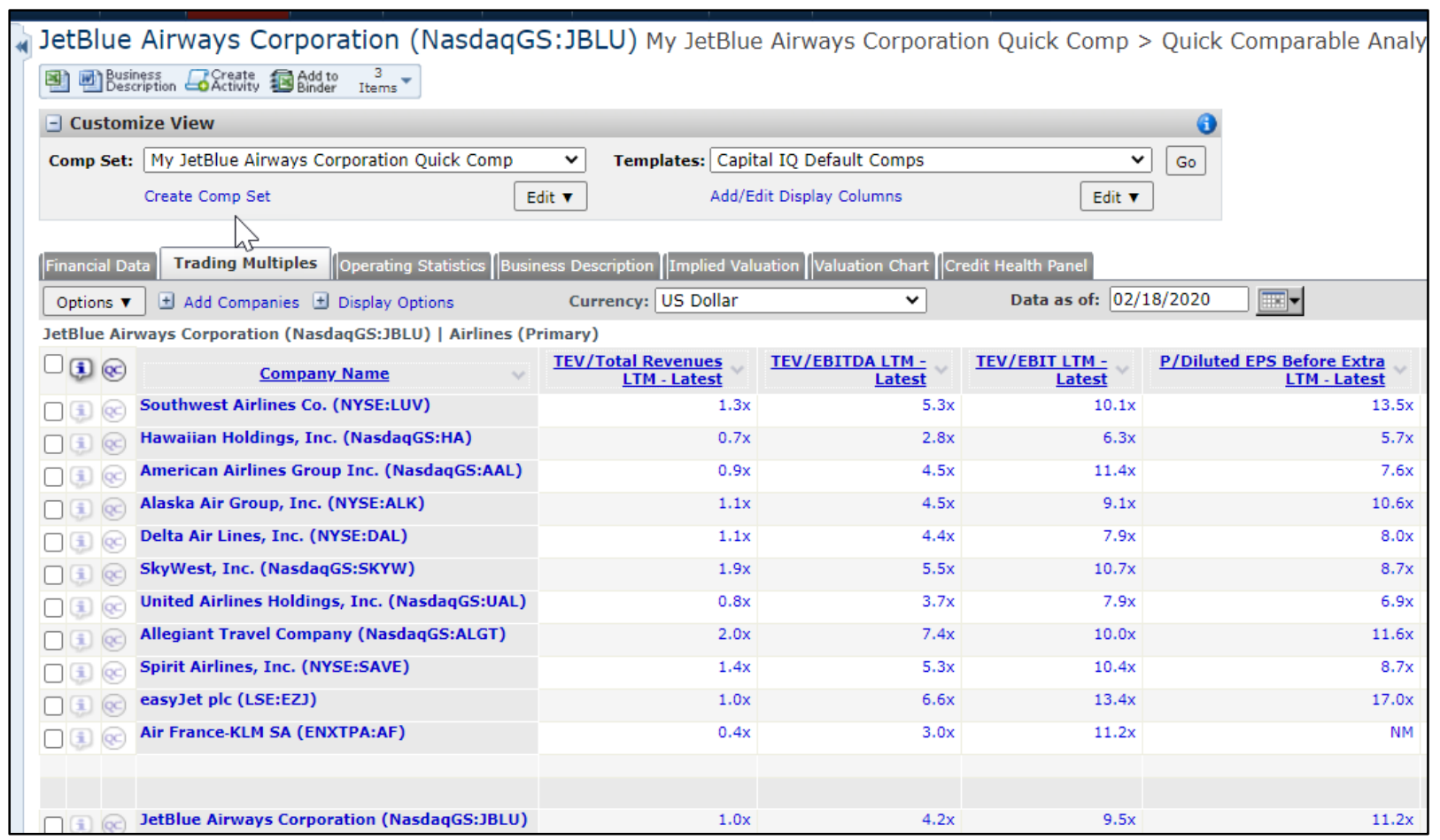

Here is a drill down of EV/EBITDA for JetBlue and Air France. You can see that lease expense has been added to get to EBITDA.

At 2/18/2020 Jet Blue's EV/EBITDA, with values in millions of dollars, is found as:

EV of 7,834.9 / EBITDA of 1,856= EV/EBITDA of 4.22

FIGURE 4

JBLU EV/EBITDA

\begin{tabular}{|c|c|c|c|c|c|}
\hline \multicolumn{6}{|c|}{ Last Close TEV/EBITDA } \\
\hline \multirow{2}{*}{\multicolumn{4}{|c|}{$\begin{array}{l}\text { JetBlue Airways Corporation } \\
\text { Standardized Data } \\
\text { Feb-18-2020 - US Dollar ( } \mathrm{mm})\end{array}$}} & & Edit $\mathbf{V}$ \\
\hline & & & & \\
\hline \multirow{2}{*}{\multicolumn{3}{|c|}{$\begin{array}{l}\text { Last Close TEV } \\
\text { EBITDA (Incl. Equity Inc. from } \\
\text { / Affiliates) } \\
\text { (as of Dec-31-2019) }\end{array}$}} & $7,834.90$ & \begin{tabular}{|l} 
EBITDA (Incl. Equity Inc. from \\
Affiliates, Lease Adjusted)
\end{tabular} & $\bar{x}$ \\
\hline & & & $1,856.00$ & $\begin{array}{l}\text { Allillates, Lease AduUstea) } \\
\text { Standardized Data } \\
\text { Dec-31-2019 - US Dollar ( } \mathrm{mm} \text { ) }\end{array}$ & \\
\hline \multirow{2}{*}{\multicolumn{2}{|c|}{$=$ Total }} & his & 4.22 & Total Revenues & $8,094.00$, \\
\hline & चस(ख) & & Col & - Cost Of Revenues & $5,359.00$ \\
\hline \multirow{6}{*}{ tion } & $\square$ (i) (c) & \multicolumn{2}{|c|}{ Southwest Airline } & $\begin{array}{l}\text { - Selling General \& Admin } \\
\text { Expenses }\end{array}$ & 290.00 \\
\hline & $\square$ (i) (8) & \multicolumn{2}{|c|}{ Hawaiian Holding } & $\begin{array}{l}\text { - Depreciation \& Amortization, } \\
\text { Total }\end{array}$ & 525.00 \\
\hline & $\square$ (i) (8) & \multicolumn{2}{|c|}{ American Airlines } & - Other Operating Expenses & $1,106.00$ \\
\hline & $\square$ ( ) (ब) & \multicolumn{2}{|c|}{ Alaska Air Group, } & + Income (Loss) On Equity Invest. & 15.00 \\
\hline & ( & \multirow{2}{*}{\multicolumn{2}{|c|}{ Delta Air Lines, In }} & \multirow{2}{*}{$\begin{array}{l}\text { + D\&A for EBITDA } \\
\text { t }\end{array}$} & 473.00 \\
\hline & $\square$ (i) (c) & & & & 554.00 \\
\hline $\begin{array}{l}\text { ummary } \\
\text { etails }\end{array}$ & $\begin{array}{l}\square \text { (i) (c) } \\
\square \text { ii) (C) }\end{array}$ & \multicolumn{2}{|c|}{$\begin{array}{l}\text { SkyWest, Inc. ( } \mathrm{N} \\
\text { United Airlines } \mathrm{H}\end{array}$} & $\begin{aligned} & \text { EBITDA (Incl. Equity Inc. } \\
&= \text { from Affiliates, Lease } \\
& \text { Adjusted) }\end{aligned}$ & $1,856.00$ \\
\hline
\end{tabular}

At 2/18/2020 Air France's EV/EBITDA, with values in millions of euros, is found as: 


\section{FIGURE 5 AIR FRANCE EV/EBITDA}

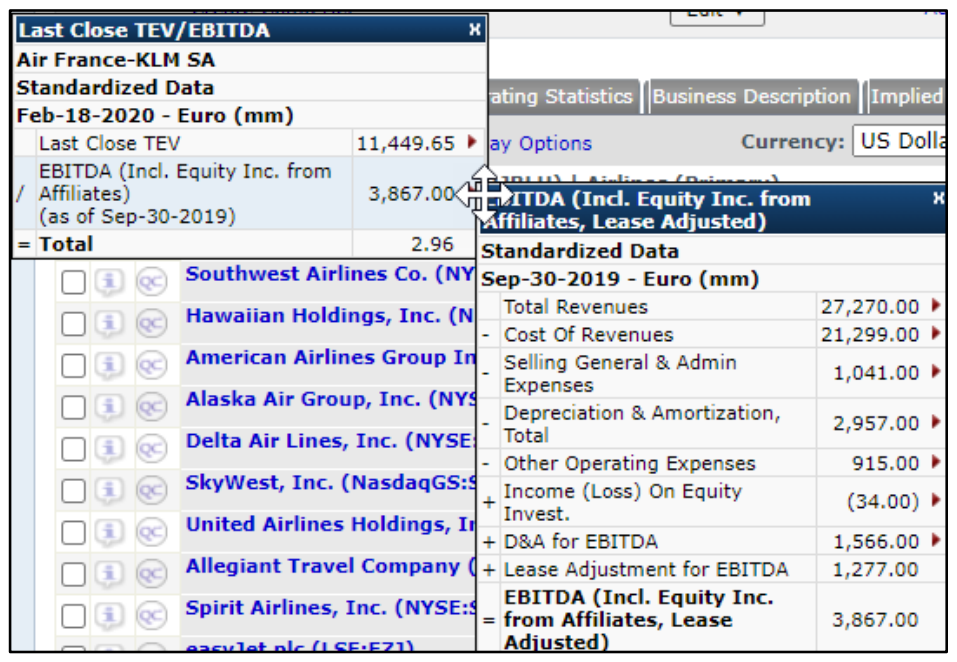

\section{KEY TAKE-AWAYS}

Financial statements now reflect the changes to accounting for leases under both the IFRS and US GAAP accounting standards. The new rules do improve comparability of some metrics but both the approach used to acquire assets and the accounting standard adopted can impact measures like EBIT, operating cash flows and debt to equity ratios.

Those involved in financial analysis and valuation should take care in calculating enterprise value, EBIT and EBITDA, and valuation multiples. Of equal importance is the clear communication of how you define and calculate measures like EBITDA and enterprise value since there is currently no clear consensus on whether and how to include operating leases in these metrics. For example, what is called EBITDA by one analyst may be referred to as EBITDAR by others. Enterprise value calculations may include or exclude operating lease obligations. When accessing data from providers like Bloomberg, Capital IQ and FactSet, ensure you understand what is being reported since these providers have adjusted the information on enterprise value, EBITDA, and other metrics in an attempt to enhance consistency across firms.

As I draft this in early 2021, I'm not sure whether Sir David Tweedie has been able to fly since implementation of IFRS 16 and ASC 842 since Covid related travel bans were initiated not long after, but if he did fly, he most likely got his wish and did indeed fly on an aircraft that actually exists on a balance sheet somewhere.

\section{REFERENCES}

Damodaran, A. (2009). Leases, Debt and Value. Working Paper, Stern School of Business, New York University. Retrieved from http://people.stern.nyu.edu/adamodar/pdfiles/papers/oplev.pdf

Deloitte. (2020, June). A Roadmap to Applying the New Leasing Standard. Retrieved from https://www2.deloitte.com/content/dam/Deloitte/us/Documents/audit/ASC/Roadmaps/us-aers-aroadmap-to-applying-the-new-leasing-standard.pdf

Gorman, M., Lyons, B., \& Tarasovich, B. (2020, February). Analyzing performance under ASC 842. Retrieved February 23, 2021, from https://sfmagazine.com/post-entry/february-2020-analyzingperformance-under-asc-842/ 
KPMG. (n.d.). ASC 842 and IFRS 16 top differences. Retrieved from https://advisory.kpmg.us/articles/2018/ifrs-16-asc-842-differences.html

Maurer, M. (2019, July 10). New Lease Accounting Standard May Mislead Investors, Credit Suisse Says. The Wall Street Journal.

Peters, S., \& Ciesielski, J. (2019). Leases: What Investors Need to Know about the New Standard. CFA Institute.

PWC. (2021, September 30). US Leases guide 1.1. Retrieved from

https://www.pwc.com/us/en/cfodirect/publications/accounting-guides/pwc-lease-accountingguide-asc-842.html

\section{APPENDIX: SELECT INFORMATION FROM JETBLUE AIRWAYS 2019 10K}

FIGURE 1

JBLU BALANCE SHEET

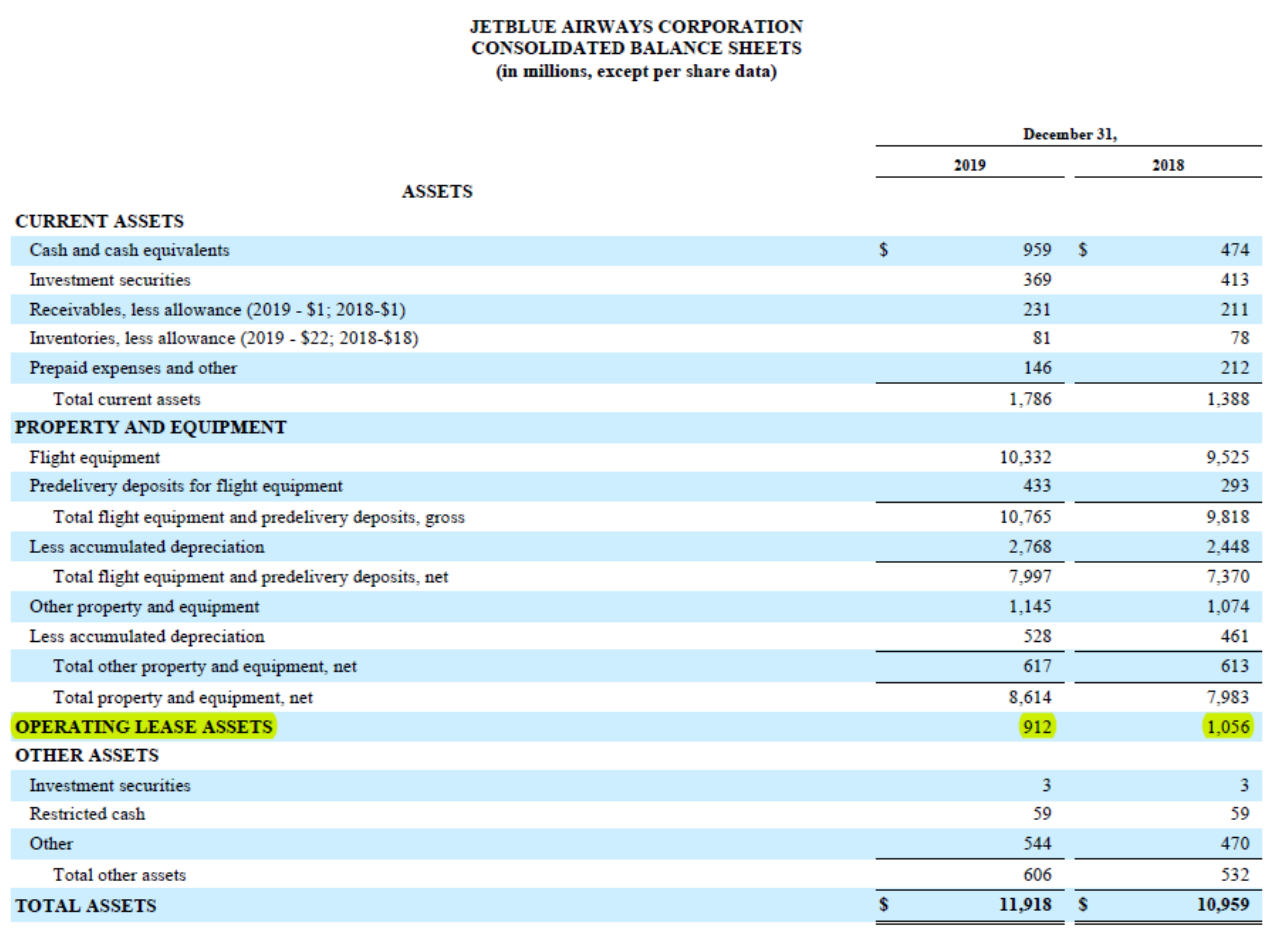

See accompanying notes to consolidated financial statements. 
JETBLUE AIRWAYS CORPORATION

(in millions, except per share data)
CONSOLIDATED BALANCE SHEE

\begin{tabular}{|c|c|c|c|c|}
\hline \multirow{2}{*}{ LIABILITIES AND STOCKHOLDERS' EQUITY } & \multicolumn{4}{|c|}{ December 31 , } \\
\hline & \multicolumn{2}{|c|}{2019} & \multicolumn{2}{|c|}{2018} \\
\hline \multicolumn{5}{|l|}{ CURRENT LIABILITIES } \\
\hline Accounts payable & $\$$ & 401 & s & 437 \\
\hline Air traffic liability & & 1,119 & & 1,035 \\
\hline Accrued salaries, wages and benefits & & 376 & & 313 \\
\hline Other accrued liabilities & & 295 & & 298 \\
\hline Current operating lease liabilities & & 128 & & 133 \\
\hline Current maturities of long-term debt and finance lease obligations & & 344 & & 309 \\
\hline Total current liabilities & & 2,663 & & 2,525 \\
\hline LONG-TERM DEBT AND FINANCE LEASE OBLIGATIONS & & 1,990 & & 1,361 \\
\hline LONG-TERM OPERATING LEASE LIABILITIES & & 690 & & 798 \\
\hline \multicolumn{5}{|l|}{ DEFERRED TAXES AND OTHER LIABILITIES } \\
\hline Deferred income taxes & & 1,251 & & 1,112 \\
\hline Air traffic liability - loyalty non-current & & 481 & & 447 \\
\hline Other & & 44 & & 31 \\
\hline Total deferred taxes and other liabilities & & 1,776 & & 1,590 \\
\hline \multicolumn{5}{|l|}{ COMMITMENTS AND CONTINGENCIES (Notes 11 \& 12) } \\
\hline \multicolumn{5}{|l|}{ STOCKHOLDERS' EQUITY } \\
\hline Preferred stock, $\$ 0.01$ par value; 25 shares authorized, none issued & & - & & - \\
\hline $\begin{array}{l}\text { Common stock, } \$ 0.01 \text { par value; } 900 \text { shares authorized, } 427 \text { and } 422 \text { shares issued and } 282 \text { and } 306 \text { shares } \\
\text { outstanding at } 2019 \text { and } 2018 \text {, respectively }\end{array}$ & & 4 & & 4 \\
\hline Treasury stock, at cost; 145 and 116 shares at 2019 and 2018 , respectively & & $(1,782)$ & & $(1,272)$ \\
\hline Additional paid-in capital & & 2,253 & & 2,203 \\
\hline Retained earnings & & 4,322 & & 3,753 \\
\hline Accumulated other comprehensive income (loss) & & 2 & & (3) \\
\hline Total stockholders' equity & & 4,799 & & 4,685 \\
\hline TOTAL LIABILITIES AND STOCKHOLDERS' EQUITY & $\$$ & 11,918 & s & 10,959 \\
\hline
\end{tabular}

FIGURE 2

JBLU NOTE ON LEASES

JETBLUE AIRWAYS CORPORATION

NOTES TO CONSOLIDATED FINANCIAL STATEMENTS

Leases with a term of 12 months or less are not recorded on the balance sheet. Our lease agreements do not contain any residual value guarantees. For facility leases, we account for the lease and non-lease components as a single lease component.

The table below presents the lease-related assets and liabilities recorded on our consolidated balance sheets as of December 31,2019 and 2018 (in millions):

\begin{tabular}{|c|c|c|c|c|c|}
\hline \multirow{2}{*}{ Assets } & \multirow{2}{*}{ Classification on Balance Sheet } & \multicolumn{4}{|c|}{ As of December 31, } \\
\hline & & \multicolumn{2}{|c|}{2019} & \multicolumn{2}{|c|}{2018} \\
\hline Operating lease assets & Operating lease assets & $\$$ & 912 & $\$$ & 1,056 \\
\hline Finance lease assets & Property and equipment, net & & 171 & & 181 \\
\hline Total lease assets & & $\$$ & 1,083 & $\$$ & 1,237 \\
\hline Liabilities & Classification on Balance Sheet & & & & \\
\hline \multicolumn{6}{|l|}{ Current: } \\
\hline Operating lease liabilities & Current operating lease liabilities & $\$$ & 128 & $\$$ & 133 \\
\hline Finance lease liabilities & Current maturities of long-term debt and finance lease obligations & & 31 & & 18 \\
\hline \multicolumn{6}{|l|}{ Long-term: } \\
\hline Operating lease liabilities & Long-term operating lease liabilities & & 690 & & 798 \\
\hline Finance lease liabilities & Long-term debt and finance lease obligations & & 58 & & 89 \\
\hline Total lease liabilities & & $\$$ & 907 & $\$$ & 1,038 \\
\hline
\end{tabular}




\section{Lease Costs}

The table below presents certain information related to our lease costs during the years ended December 31, 2019, 2018, and 2017 (in millions):

\begin{tabular}{|c|c|c|c|c|c|c|}
\hline \multirow[b]{2}{*}{ Operating lease cost } & \multicolumn{2}{|c|}{2019} & \multicolumn{2}{|c|}{2018} & \multicolumn{2}{|c|}{2017} \\
\hline & $\$$ & 180 & $\$$ & 185 & $\$$ & 180 \\
\hline Short-term lease cost & & 2 & & 2 & & 2 \\
\hline \multicolumn{7}{|l|}{ Finance lease cost: } \\
\hline Amortization of assets & & 9 & & 10 & & 10 \\
\hline Interest on lease liabilities & & 3 & & 3 & & 4 \\
\hline Variable lease cost & & 391 & & 379 & & 358 \\
\hline Sublease income & & (19) & & $(15)$ & & (14) \\
\hline Total net lease cost & $\$$ & 566 & $\$$ & 564 & $\$$ & 540 \\
\hline
\end{tabular}

Other Information

The table below presents supplemental cash fletinformation related to leases during the years ended December 31, 2019, 2018, and 2017 (in millions):

\begin{tabular}{|c|c|c|c|c|c|c|}
\hline \multicolumn{3}{|c|}{2019} & \multicolumn{2}{|c|}{2018} & \multicolumn{2}{|c|}{2017} \\
\hline Cash paid for amounts included in the meas & & & & & & \\
\hline Operating cash flows for operating leases & $\$$ & 136 & $\$$ & 151 & $\$$ & 150 \\
\hline Operating cash flows for finance leases & & 5 & & 5 & & 6 \\
\hline Financing cash flows for finance leases & & 17 & & 17 & & 16 \\
\hline
\end{tabular}

Lease Commitments

The table below presents scheduled future minimum lease payments for operating and finance leases recorded on our consolidated balance sheets, as of December 31, 2019 (in millions):

\begin{tabular}{|c|c|c|c|c|}
\hline \multirow[b]{3}{*}{2020} & \multicolumn{4}{|c|}{ As of December 31, 2019} \\
\hline & \multicolumn{2}{|c|}{ Operating Leases } & \multicolumn{2}{|c|}{ Finance Leases } \\
\hline & $s$ & 128 & $\$$ & 35 \\
\hline 2021 & & 122 & & 39 \\
\hline 2022 & & 114 & & 9 \\
\hline 2023 & & 104 & & 9 \\
\hline 2024 & & 95 & & 5 \\
\hline Thereafter & & 565 & & - \\
\hline Total minimum lease payments & & 1,128 & & 97 \\
\hline Less: amount of lease payment representing interest & & $(310)$ & & $(8)$ \\
\hline Present value of future minimum lease payment & & 818 & & 89 \\
\hline Less: current obligations under leases & & $(128)$ & & (31) \\
\hline Long-term lease obligations & $\$$ & 690 & $\$$ & 58 \\
\hline
\end{tabular}

We did not have any lease commitments that have not yet commenced as of December 31,2019

As of December 31,

\begin{tabular}{|c|c|c|}
\hline \multirow{2}{*}{\multicolumn{3}{|c|}{ Weighted average remaining lease term (in years) }} \\
\hline & & \\
\hline Operating leases & 11 & 11 \\
\hline Finance leases & 3 & 4 \\
\hline \multicolumn{3}{|c|}{ Weighted average discount rate } \\
\hline Operating leases & $5.95 \%$ & $5.95 \%$ \\
\hline Finance leases & $4.75 \%$ & $4.73 \%$ \\
\hline
\end{tabular}

